\title{
THE EFFECT OF PROBIOTICS WITH DIFFERENT DOSAGES ON THE GROWTH OF VANAME SHRIMP (Litopenaeus vannamei)
}

\author{
Mahfud Akbar ${ }^{1 *}$,Muhammad Junaidi ${ }^{1}$, Fariq Azhar ${ }^{1}$ \\ ${ }^{1}$ Aquaculture Study Program, Faculty of Agriculture, Mataram University, Pendidikan St 37, \\ Mataram, Nusa Tenggara Barat, Indonesia
}

*Correspondence :

akbarmahfud96@gmail.com

Received : 2021-05-21

Accepted : 2021-06-23

Keywords :

growth, shrimp, and

probiotics

\section{ABSTRACT}

Research on the effect of probiotic dosing on the growth of vaname shrimp (Litopenaeus vannamei). This research was conducted for 45 days from 26 August to 14 October 2019 which took place at UD Kolbun Nanda Mumbul Sari Village, Bayan District, North Lombok Regency, West Nusa Tenggara (NTB). This study used the CRD method (completely randomized design) with 5 treatments and 3 replications. The container used in this study was a sterofome with $\mathrm{p} 82 \times 50 \times 38 \mathrm{~cm}$, so that the area of the container used was $155,800 \mathrm{~cm} 3$ and the volume of water in the container was 50 liters. The containers used were 15 sterofom units with 5 treatments and 3 replications, where in treatment one (P1) used probiotics at a dose of $0.2 \mathrm{ml} / \mathrm{l} /$ week, treatment two (P2) used probiotics at a dose of $0.4 \mathrm{ml}$ / I / week, treatment three (P3) used probiotics at a dose of $0.6 \mathrm{ml} / \mathrm{I} /$ week, treatment four (P4) used probiotics at a dose of $0.8 \mathrm{ml} / \mathrm{I} /$ week, and treatment five (P5) used probiotics at a dose of $1 \mathrm{ml} / \mathrm{l}$ / week. Parameters observed during the study included growth rate, survival rate (SR), and feed conversion ratio (FCR) of vanname shrimp. The results showed that the administration of probiotics with different doses did not have a significant effect on growth in absolute weight and growth in daily weight. However, it had a significantly different effect on the survival rate and feed conversion ratio.

\section{INTRODUCTION}

Vannamei shrimp (Litopenaeus vannamei) is one of the shrimp that has high economic value in Indonesia, in addition to tiger shrimp (Panaeus monodon) and white shrimp (Panaeus merguensis). Vannamei shrimp has a selling price of Rp. 40,000 to Rp. 90,000 with a maintenance age of 60 to 90 days (Hidayatullah, 2016). This is indicated by the increased production of vaname shrimp in 2011 by 246,420 tons, in 2012 by 251,763 tons and in 2013 by 386,314 tons (KKP, 2015). The development of this species is due to the advantages possessed by vaname shrimp, including having a relatively high adaptability to environmental changes such as changes in temperature and salinity (Adiwidjaya et al., 2003). 
Journal of Fish Health Vol. 1 (1) - Juni 2021

Akbar et al. (2021)

https://doi.org/10.29303/jfh.v1i1.162

The rapid development of aquaculture activities with the application of intensive systems has led to problems in the form of a decrease in the carrying capacity of ponds for the life of fish or shrimp that are cultivated. The further impact is the occurrence of a series of disease attacks that cause huge losses. Anticipatory steps through the application of cultivation technology based on the rules of ecosystem balance are a solution to prevent more serious damage. Among these steps is through the application of probiotics that have the ability to maintain water quality and inhibit the growth of pathogenic microorganisms in order to create a sustainable aquaculture system (Khasani, 2011).

With the increasing number of diseases that appear in cultivation activities, where these diseases are thought to be caused by viral and pathogenic infections (Ridlo and Pramesti, 2009). Therefore, it is necessary to apply technology that can be applied in cultivation activities. The expected technology is technology that is cheap, practical, and effective. One technology that can be applied to shrimp farming is through the use of probiotics.

According to Lara-Flores (2011), probiotics are generally defined as microorganisms that have the ability to modify the composition of bacteria in the digestive tract of aquatic animals, water, and sediments and can be used as feed supplements that can improve host health and act as biocontrol agents. Mayasari (2013) added that probiotics function to improve water quality, increase immune response and nutrition, and get rid of pathogenic bacteria.

Wang et al. (2007) in Ahmadi (2012) explained that probiotic bacteria produce enzymes that are able to break down complex compounds into simple ones so that they are ready for use. In improving feed nutrition, the bacteria contained in probiotics has a mechanism in the intestines by releasing several enzymes for feed digestion such as amylase, lipase and protease. These enzymes will help hydrolyze feed nutrients (complex molecules), such as breaking down carbohydrates, fats and proteins into simpler molecules so that it will facilitate the process of digestion and absorption in the digestive tract of fish (Putra, 2010).

Based on the description above, it is necessary to do research on the effect of giving probiotics with different doses on the growth of white shrimp (Litopenaeus vannamei). This study aims to determine the effect of the dose of probiotics on the growth of white vannamei shrimp (Litopenaeus vannamei) and to determine the appropriate dose of probiotics for the growth of vannamei shrimp (Litopenaeus vannamei).

\section{METHODOLOGY}

\section{Materials and tools}

The materials used in this study were sea water, vannamei shrimp, probiotics, artificial feed. The tools used in this research are steroform, blower, $\mathrm{pH}$ meter, thermometer, refractometer, DO meter, scales, ruler, camera.

Research methods

The test animals used were vaname shrimp, the shrimp used were 1 month old seeds weighing 3-5 grams. Maintenance was carried out for 45 days in a styrofoam container with a volume of $50 \mathrm{~L}$. This study used the RAL method (Completely Randomized Design) with 5 treatments and 3 replications, namely treatment (P1) using Bacillus sp. with a dose of 0.2 $\mathrm{ml} / \mathrm{l} /$ week, treatment (P2) using Bacillus sp. with a dose of $0.4 \mathrm{ml} / \mathrm{l} /$ week, treatment (P3) using Bacillus sp. with a dose of $0.6 \mathrm{ml} / \mathrm{l} /$ week, treatment (P4) using Bacillus sp. with a dose of $0.8 \mathrm{ml} / \mathrm{l} /$ week and treatment (P5) using Bacillus sp. at a dose of $1 \mathrm{ml} / \mathrm{l} /$ week.

Data analysis 
Journal of Fish Health Vol. 1 (1) - Juni 2021

Akbar et al. (2021)

https://doi.org/10.29303/jfh.v1i1.162

Data that has been collected during the research process was analyzed using ANOVA (analysis of variance) at the $5 \%$ level and further BNT test (smallest significant difference) was performed at $5 \%$ significance level if the results showed significant differences.

\section{RESULT}

\section{Absolute Weight Growth Rate}

The results of the analysis of the absolute weight growth of vaname shrimp during the 45 days of rearing showed that there was no difference in the absolute weight growth of vaname shrimp given different doses of probiotics in each treatment $(p>0.05)$ (Figure 1).

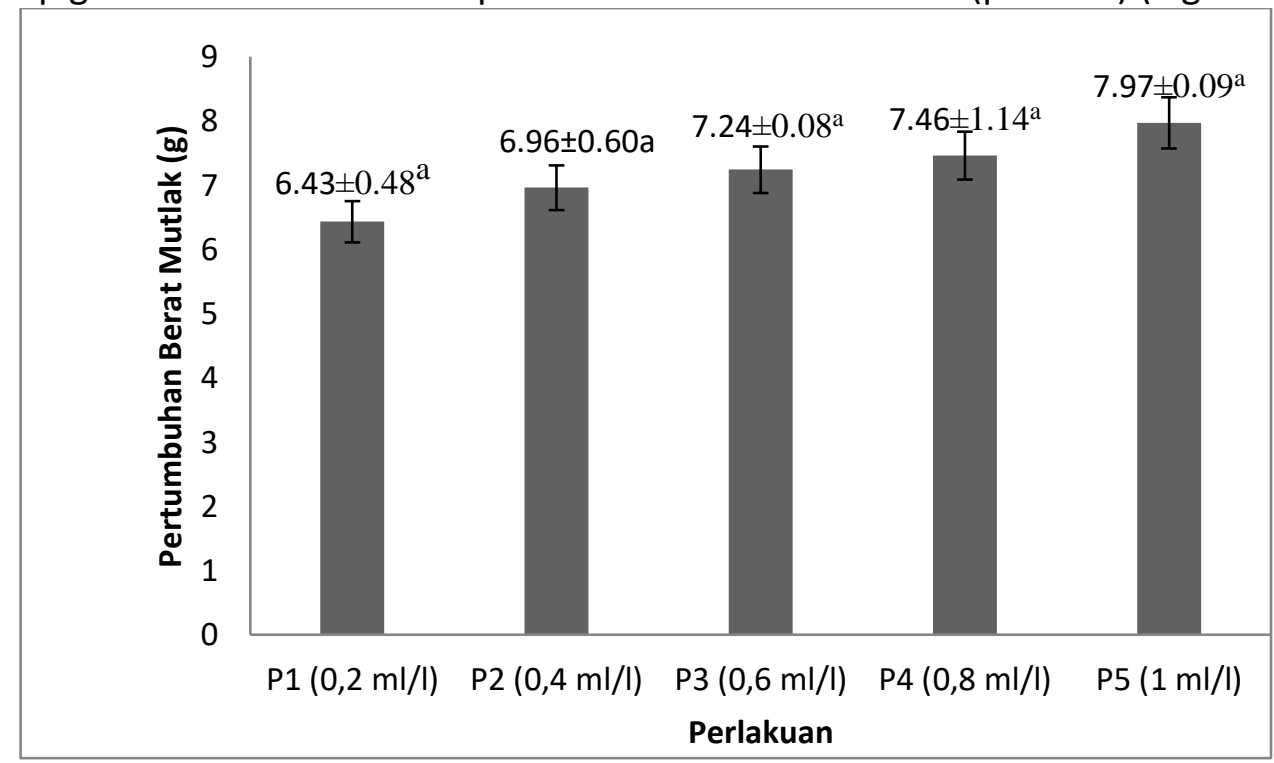

Figure1. Absolute Weight Growth Rate

Based on Figure 1. shows that probiotics at a dose of $1 \mathrm{ml} / \mathrm{l} /$ week (P5) gave the highest average absolute weight growth of white vaname shrimp, which was $7.97 \mathrm{~g}$, followed by a dose of $0.8 \mathrm{ml} / \mathrm{l} /$ week, respectively. (P4) of $7.46 \mathrm{~g}$, dose of $0.6 \mathrm{ml} / \mathrm{l} /$ week (P3) of $7.24 \mathrm{~g}$, dose of $0.4 \mathrm{ml} / \mathrm{l} /$ week (P2) of $6.96 \mathrm{~g}$ and the lowest absolute weight was found in a dose of $0.2 \mathrm{ml} / \mathrm{l} /$ week (P1) of $6.43 \mathrm{~g}$. The results of analysis of variance showed that the use of different doses of probiotics had no significant effect $(p>0.05)$ on the absolute weight growth of white vaname shrimp.

\section{Daily Weight Growth Rate}

The results of the analysis of the absolute weight growth of vaname shrimp during the 45 days of rearing, showed that there was no difference in the daily weight growth of white vaname shrimp given different doses of probiotics in each treatment $(p>0.05)$ (Figure 2). 
Journal of Fish Health Vol. 1 (1) - Juni 2021

Akbar et al. (2021)

https://doi.org/10.29303/jfh.v1i1.162

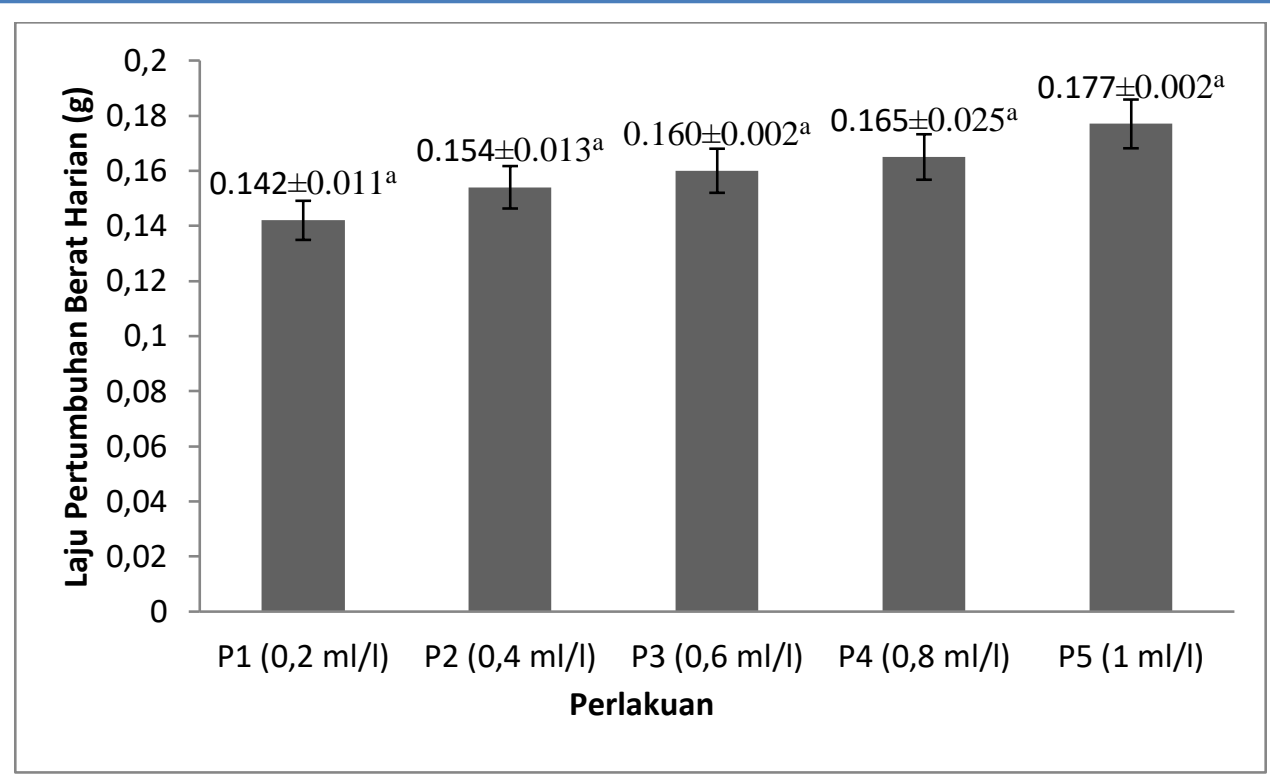

Figure 2. Daily Weight Growth Rate

Based on Figure 2. shows that the probiotic at a dose of $1 \mathrm{ml} / \mathrm{l} /$ week (P5) gave the highest average daily weight growth of white vaname shrimp, which was $0.177 \mathrm{~g}$, followed by a dose of $0.8 \mathrm{ml} / \mathrm{l} /$ week ( P4) of $0.165 \mathrm{~g}$, a dose of $0.6 \mathrm{ml} / \mathrm{l} /$ week (P3) of $0.160 \mathrm{~g}$, a dose of $0.4 \mathrm{ml} / \mathrm{l} /$ week (P2) of $0.154 \mathrm{~g}$ and the lowest absolute weight was found at a dose of $0.2 \mathrm{ml} / \mathrm{l}$ /week (P1) of $0.142 \mathrm{~g}$. The results of analysis of variance showed that the use of different doses of probiotics had no significant effect $(p>0.05)$ on the daily weight growth of vaname shrimp.

\section{Survival Rate}

The results of the analysis of the absolute weight growth of vannamei shrimp during the 45 days of rearing showed that there were differences in the survival rate of vannamei shrimp given different doses of probiotics in each treatment $(p<0.05)$ (Figure 3 ).

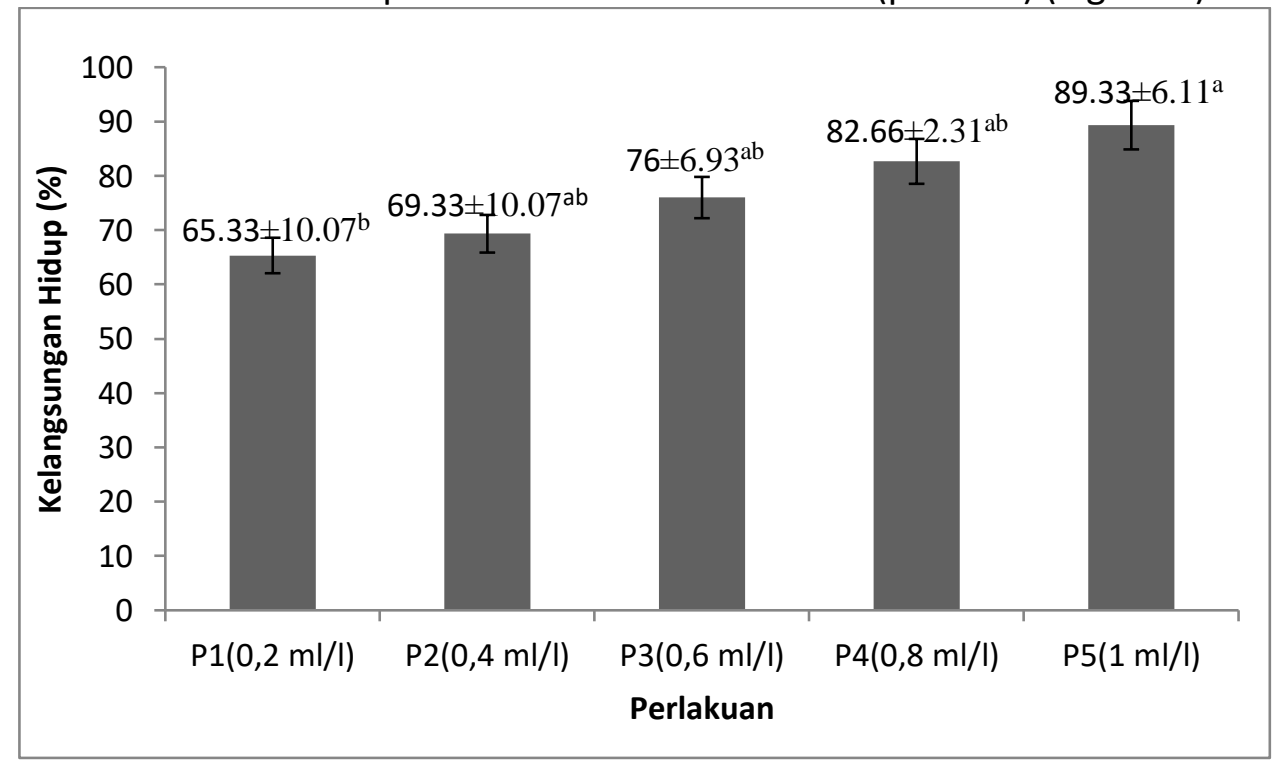

Figure 3. Survival Rate 
Journal of Fish Health Vol. 1 (1) - Juni 2021

Akbar et al. (2021)

https://doi.org/10.29303/jfh.v1i1.162

Based on Figure 3. shows that probiotics at a dose of $1 \mathrm{ml} / \mathrm{l} /$ week (P5) gave the highest average value for the survival rate of white vaname shrimp, which was $89.33 \%$, followed by a dose of $0.8 \mathrm{ml} / \mathrm{l} /$ respectively. week (P4) was $82.66 \%$, dose $0.6 \mathrm{ml} / \mathrm{l} /$ week (P3) was $76 \%$, dose $(0.4 \mathrm{ml} / \mathrm{l} /$ week (P2) was $69.33 \%$ and the lowest survival rate was found at a dose of $0.2 \mathrm{ml} / \mathrm{l} /$ week (P1) of $65.33 \%$.

The results of analysis of variance showed that the use of different doses of probiotics had a significant effect $(p<0.05)$ on the survival rate of vaname shrimp, so a further BNT test was carried out to determine the best treatment. Further test results showed that the dose of $1 \mathrm{ml} / \mathrm{l} /$ week (P5) was not significantly different from a dose of 0.8 $\mathrm{ml} / \mathrm{l} /$ week (P4), a dose of $0.6 \mathrm{ml} / \mathrm{l} /$ week (P3), and a dose of $0.4 \mathrm{ml} / \mathrm{l} /$ week (P2) but significantly different with a dose of $0.2 \mathrm{ml} / \mathrm{l} /$ week (P1).

\section{Feed Conversion Ratio}

The results of the analysis of the absolute weight growth of vaname shrimp during the 45 days of rearing, showed that there were differences in the value of the conversion ratio of vaname shrimp feed given different doses of probiotics in each treatment $(p<0.05)$ (Figure 7).

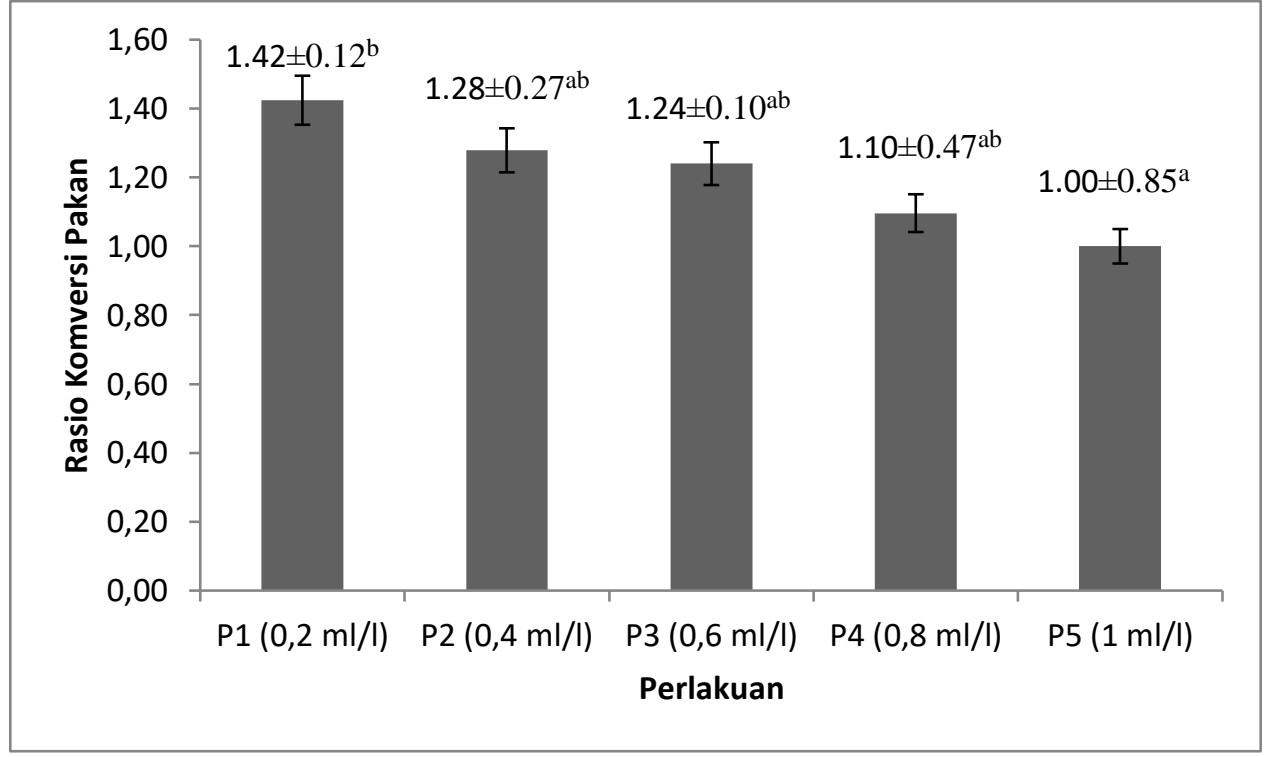

Figure 4. Feed Conversion Ratio

Based on Figure 4. shows that probiotics with a dose of $1 \mathrm{ml} / \mathrm{l} / \mathrm{week}$ (P5) gave the best average value for vaname shrimp feed conversion, which was 1.00 , followed by a dose of $0.8 \mathrm{ml} / \mathrm{l} /$ week. (P4) of 1.10, a dose of $0.6 \mathrm{ml} / \mathrm{I} /$ week (P3 ) of 1.24, a dose of $0.4 \mathrm{ml} / \mathrm{I} /$ week (P2) of 1.28 and the lowest feed conversion are on a dose of $0,2 \mathrm{ml} / \mathrm{l} /$ week (P1) is 1.42 .

Results of analysis of variance showed that the use of doses of probiotics b erbeda significant $(p<0,05)$ against the value of shrimp feed conversion vaname, so that a further test of BNT to determine the best treatment. Further test results showed that the dose of 1 $\mathrm{ml} / \mathrm{l} /$ week (P5) was not significantly different from the dose of $0.8 \mathrm{ml} / \mathrm{l} /$ week (P4), the dose of $0.6 \mathrm{ml} / \mathrm{l} /$ week (P3), and the dose of $0.4 \mathrm{ml} / \mathrm{l} /$ week (P2) but it was significantly different with a dose of $0.2 \mathrm{ml} / \mathrm{l} /$ week (P1). 
Journal of Fish Health Vol. 1 (1) - Juni 2021

Akbar et al. (2021)

https://doi.org/10.29303/jfh.v1i1.162

\section{Water quality}

The results of observations of water quality for 45 days of rearing showed that the values of the temperature range, salinity, $\mathrm{pH}$, and $\mathrm{DO}$ were still within the limits of the feasibility of rearing white shrimp (Figures 8, 9, 10, and 11 ). Water quality has an important role to support the life and growth of white vaname shrimp.

Temperature

The results of temperature observations during the study were, treatment P1 0.2 $\mathrm{ml} / \mathrm{l} /$ week) ranged from 26.3-29.9 ${ }^{\circ} \mathrm{C}$, treatment $\mathrm{P} 2$ (0.4 ml/l/week) ranged from 26.3-29 0.7 ${ }^{\circ} \mathrm{C}$, treatment $\mathrm{P} 3\left(0.6 \mathrm{ml} / \mathrm{l} /\right.$ week) ranged from $25.7-29.1^{\circ} \mathrm{C}$, treatment $\mathrm{P} 4(0.8 \mathrm{ml} / \mathrm{l} /$ week $)$ ranged from $25.5-30,0{ }^{\circ} \mathrm{C}$, treatment $\mathrm{P} 5(1 \mathrm{ml} / \mathrm{l} /$ week $)$ ranged from $25.7-29.7^{\circ} \mathrm{C}$.

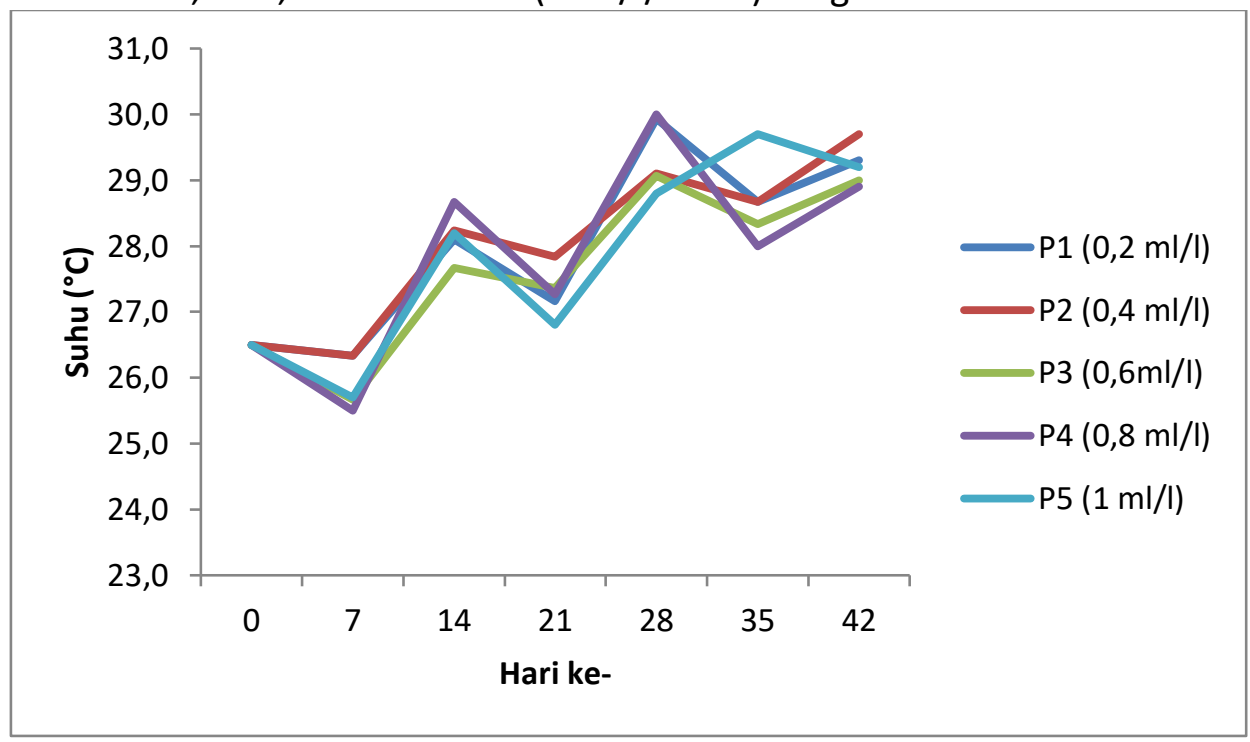

Figure 5. Temperature Value

Salinity

The results of observations of salinity during the study were, treatment P1 $(0.2$ $\mathrm{ml} / \mathrm{l} /$ week) ranged from 23-28 ppt, treatment P2 (0.4 ml/l/week) ranged from 23-27 ppt, treatment P3 (0 $6 \mathrm{ml} / \mathrm{l} /$ week) ranged from 23-27 ppt, treatment P4 $(0.8 \mathrm{ml} / \mathrm{l} /$ week) ranged from 23-27 ppt, treatment P5 (1 ml/l/week) ranged from 23-27 ppt .

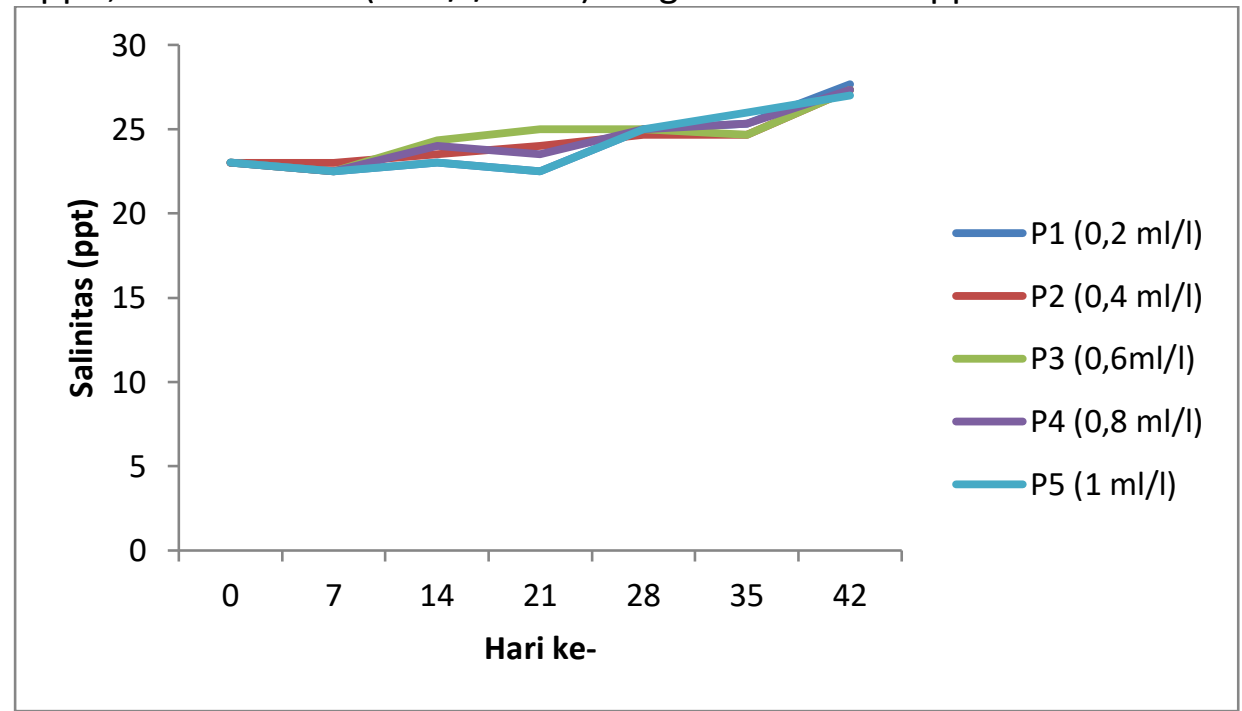

Figure 6. Salinity Value 
Journal of Fish Health Vol. 1 (1) - Juni 2021

Akbar et al. (2021)

https://doi.org/10.29303/jfh.v1i1.162

\section{Degree of Acidity ( $\mathrm{pH}$ )}

The results of the observation of the degree of acidity $(\mathrm{pH})$ during the study, namely, treatment P1 (0.2 ml/l/week) ranged from 6.7 to 7.3 , treatment P2 $(0.4 \mathrm{ml} / \mathrm{l} /$ week $)$ ranged from $6.3-7,7$, treatment $\mathrm{P} 3$ (0.6 ml/l/week) ranged from 6.7-8.0, treatment P4 (0.8 $\mathrm{ml} / \mathrm{l} /$ week) ranged from 6.7-7.0, treatment P5 (1 ml/l/week) ranged from 6.7 to 7.7.

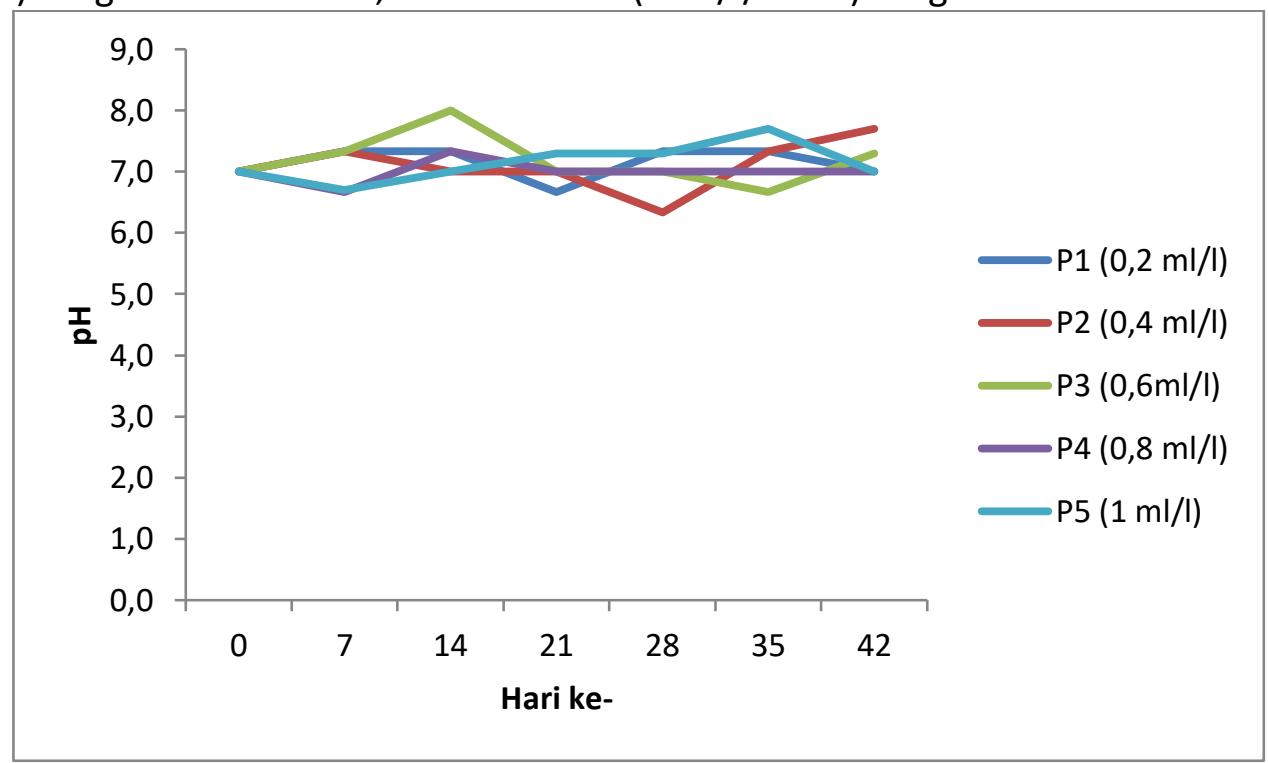

Figure 7. Values of $\mathrm{pH}$

Dissolved oxygen (DO)

The results of observations of dissolved oxygen (DO) during the study were, treatment P1 $(0.2 \mathrm{ml} / \mathrm{l} /$ week) ranged from 4.0 to $4.7 \mathrm{mg} / \mathrm{l}$, treatment P2 $(0.4 \mathrm{ml} / \mathrm{l} /$ week) ranged from 4.0-5.7 mg/l, treatment P3 (0.6 ml/l/week) ranged from 4.0-5.1 mg/l, treatment P4 (0.8 ml/l/week) ranged from 4.0-5.2 $\mathrm{mg} / \mathrm{l}, \mathrm{P} 5$ treatment $(1 \mathrm{ml} / \mathrm{l} /$ week) ranged from 4.0$5.2 \mathrm{mg} / \mathrm{l}$.

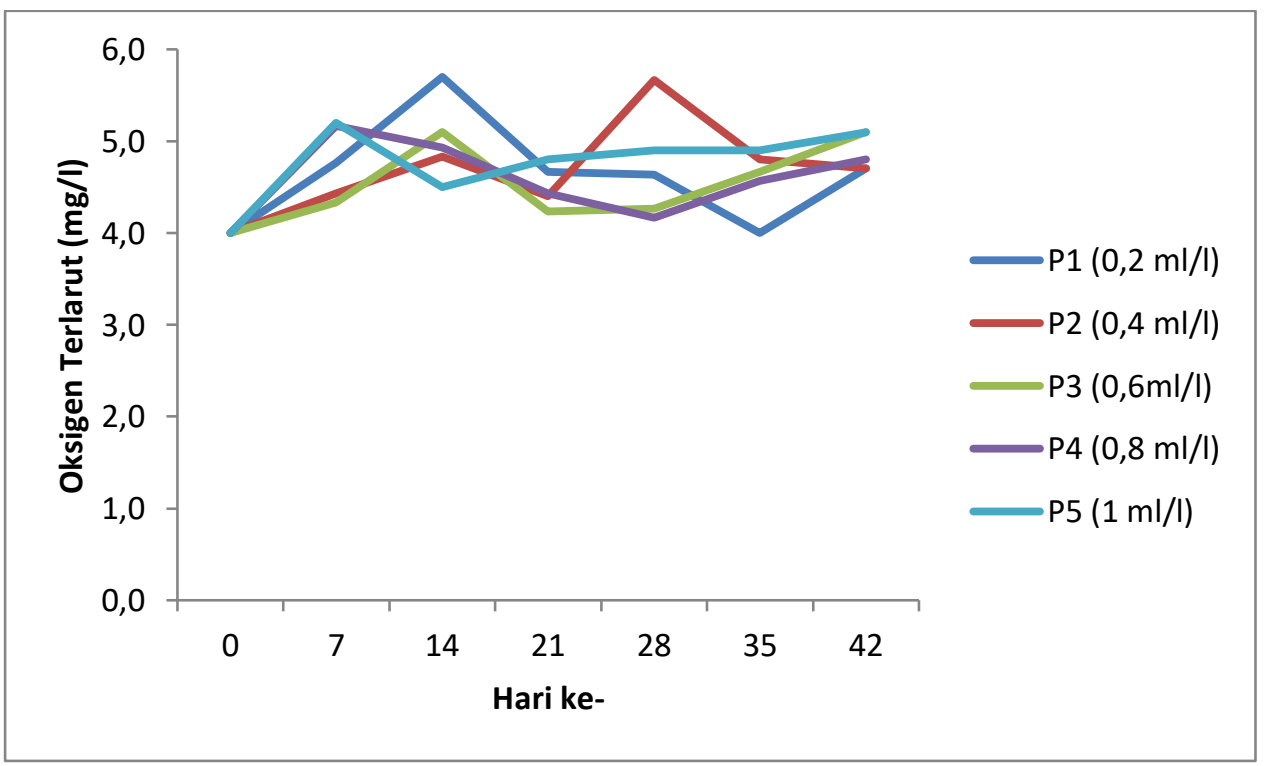

Figure 8 . Dissolved Oxygen Value 
Journal of Fish Health Vol. 1 (1) - Juni 2021

Akbar et al. (2021)

https://doi.org/10.29303/jfh.v1i1.162

\section{DISCUSSION}

Absolute growth was calculated based on the initial weight and final weight of vaname shrimp. The results of data analysis showed that absolute weight growth with different doses of probiotics did not give a significant effect on the absolute weight growth of white vaname shrimp. However, the $1 \mathrm{ml} / \mathrm{l} /$ week (P5) treatment gave the highest growth value compared to other treatments.

The high absolute weight at a dose of $1 \mathrm{ml} / \mathrm{l} /$ week compared to other treatment doses in this study was thought to be due to the dose of probiotics added to the maintenance medium. During the study, it was shown that the higher the dose of probiotics given, the higher the absolute growth value produced. This was presumably because the P5 treatment contained more beneficial microorganisms that helped the growth of shrimp. This is in accordance with the opinion of Poernomo, (2004), which states that probiotics are microorganisms that have the ability to support the growth and productivity of shrimp, so that they function as bioremediation, biocontrol, immunostimulant, and stimulate the growth of fish and shrimp. According to Wang (2007), also stated that probiotic bacteria will significantly increase digestive activity in shrimp bodies, compared to those without using probiotics in their maintenance. The bacteria contained in the commercial probiotics used in this study consisted of Bacillus sp. Pseudomonas sp. Nitrosomonas sp. Aerobacter sp. and Nitrobacter sp. it's from super-NB probiotics. While the bacteria in super-PS, namely Rhodobacter sp. and Rhodococous sp. This information is obtained from the probiotic packaging brand.

According to Wang et al, (1999) that the most important function of using probiotics is to maintain the stability of pond water quality parameters by reducing organic matter such as ammonia, hydrogen sulfide gas, and other toxic gases. In addition, probiotics also control the occurrence of algal blooms so that they can maintain a stable $\mathrm{pH}$ value in the pond, reduce $B O D$ levels, and maintain the availability of oxygen for shrimp growth. The results of research Nasrul (2019) the effect of probiot ik in different doses, that the addition of probiotics to a dose of $2 \mathrm{ml}$ significant effect on the growth of shrimp vaname absolute weight. This is thought to be due to the fact that at that dose the probiotics that enter the shrimp's digestion are more optimal and there is also a lot of natural feed available due to low levels of ammonia which causes natural feed to grow well due to ammonia which has been nitrified by nitrobacter bacteria, and natural feed can optimize performance. vaname shrimp digestion and facilitate the absorption of feed.

The results of data analysis showed that the daily weight growth with treatment with different doses of probiotics did not have a significant effect on the daily weight growth of white vaname shrimp. However, the $1 \mathrm{ml} / \mathrm{l} /$ week (P5) treatment gave the highest growth value compared to other treatments. It is suspected that there was more bacterial growth at a dose of $1 \mathrm{ml} / \mathrm{l} /$ week because the dose given was higher than the other treatments. This can be seen from the daily growth at a dose of $1 \mathrm{ml} / \mathrm{l} /$ week (P5) which was higher than the other treatment doses. With the presence of these bacteria which function to decompose organic matter in water and balance microorganisms in the digestion of fish so that the absorption rate is high. According to Soccol et al., (1993) in Widanarni (2010), probiotics are useful in regulating the microbial environment in the intestines, blocking intestinal pathogenic microorganisms and improving feed efficiency by releasing enzymes that can help the digestive process of food. The mechanism of action of probiotics includes production and competition for available compounds or energy sources, competition for 
Journal of Fish Health Vol. 1 (1) - Juni 2021

Akbar et al. (2021)

https://doi.org/10.29303/jfh.v1i1.162

attachment sites, increased immune response (immune), improved water quality, interactions with phytoplankton, sources of macro and micro nutrients, and the contribution of enzymes to digestion.

Therefore, the administration of probiotics at a dose of $1 \mathrm{ml} / \mathrm{l} /$ week (P5) can increase the specific weight of vaname shrimp. It is suspected that the addition of higher doses of probiotics can accelerate microbial growth, through the microbes contained in the probiotics, namely the Lactobacillus group, which is able to increase shrimp appetite so that it can optimize the utilization of feed nutrients with the help of Bacillus sp. proteolytic in nature. The amount of probiotic bacteria given in shrimp rearing can affect the growth of shrimp, where these bacteria can help improve water quality and shrimp digestion process, thus providing good growth. While the outcome was lowest for the doses of $0,2 \mathrm{ml} / \mathrm{I} /$ week ( P1 ). The low daily growth rate in this treatment is thought to be due to the low dose of probiotics given so that the lack of host microbiological balancing processes by microbes contained in probiotics. According to Kordi and Andi (2007), the environment has a very big influence on the growth conditions of shrimp, a polluted environment will result in decreased biota conditions so that they are susceptible to disease, which in principle, diseases that attack farmed shrimp do not just come.

However, in this study during rearing, the growth of vaname shrimp remained in normal conditions, there were several factors that influenced the growth of shrimp, namely, environmental conditions, host conditions, and the presence of pathogenic bodies. Between the environment, the host, and the body of the organism that is not balanced causes stress to the shrimp. So that the self-defense mechanism that is owned becomes weak so that the cultured biota is susceptible to disease. This can be seen from the low value of growth and survival value.

Meanwhile, the results of Syaiful's (2015) research on the provision of commercial probiotics in feed on the growth rate and feed efficiency of white vaname shrimp showed that the administration of different doses of probiotics had a significantly different effect on the daily weight growth rate of white vaname shrimp. It changes are application- $\mathrm{n}$ because of the active role of bacteria in the digestive tract, especially bacteria Lactobacillus sp., Ntirobacter sp., Geobacillus sp., And Nitrosomonas sp. Lactobacillus bacteria will convert carbohydrates into lactic acid, then lactic acid can create an acidic $\mathrm{pH}$ atmosphere. In an acidic state, Lactobacillus having the ability to inhibit bacteria pat Ogen and spoilage bacteria that exist (Delgado et al., 2001 in Syaiful 2015).

Value viability live shrimp vaname during the study ranged from $65,33 \%$ to $89.33 \%$. This indicates that the application of probiotics with different doses has a significantly different effect or significantly on the survival rate of white vaname shrimp. The highest survival was $89,33 \%$ was obtained at a dose of $1 \mathrm{ml} /$ / / week ( P5 ). Meanwhile, the lowest survival rate of $65.33 \%$ was obtained at a dose of $0.2 \mathrm{ml} / \mathrm{l} /$ week ( P1), this was due to the role of Lactobacillus bacteria contained in probiotics that were able to improve the water quality of the vannamei shrimp rearing media. In addition, probiotics are also a source of feed for shrimp so that they can suppress cannibalism. This is in accordance with the statement of Nengsih (2015), which states that the application of probiotics in aquaculture activities can improve water quality.

Furthermore Harefa (1996), adding that the factors that most influence graduation rates shrimp larvae live vaname namely water quality in maintenance media. Good water quality in maintenance media will support metabolic processes in physiological processes. Meanwhile, Suryanto and Mangampa (2010) who conducted a study on the application of 
Journal of Fish Health Vol. 1 (1) - Juni 2021

Akbar et al. (2021)

https://doi.org/10.29303/jfh.v1i1.162

probiotics with different concentrations in the rearing of vannamei shrimp gave a significantly different effect on the survival rate of vannamei shrimp.

According to Cahyono (2009), the survival rate in shrimp farming is influenced by several factors including abiotic and biotic factors. Abiotic factors include physical factors and chemical factors or often referred to as water quality. Good water quality will cause physiological processes in the body of cultivated biota to run well, thus supporting the growth and survival rate of biota. Biotic factors can also influence, including predators, food, and space.

The feed conversion value shows how much feed is consumed into fish body biomass. Results of analysis that leads $\mathrm{k}$ right that the administration of probiotics with different doses provide significantly different effect on the growth of shrimp vaname. Use values of feed conversion are best for maintenance of the pad contained a dose of $1 \mathrm{ml} / \mathrm{I} /$ week (P5) with a value of 1 , and the value of feed conversion lows contained in doses of 0,2 $\mathrm{ml} / \mathrm{l} /$ week (P1) of 1.42 (Figure 3). This is presumably because the dose of $1 \mathrm{ml} / \mathrm{l} /$ week (P5) are bacteria Bacillus sp. more than the other treatments. This is in accordance with the statement of Ridlo and Subagiyo (2013) that the low value of the feed conversion ratio is due to the role of Bacillus sp. in the form of probiotics that can produce extracellular enzymes in increasing the digestibility of food ingredients in the shrimp intestines so that they are easily absorbed by the white shrimp body.

According Mudjiman (2011), the conversion of food to the fish ranged between 1,5 1.8, meaning the value of feed conversion in all treatments can be good, because it is generally still in range. Thus the feed given has a fairly good quality, because the feed given can actually be utilized by fish for maximum weight growth. According to Saltin et al., (2016), the low feed conversion value indicates that the feed provided is almost fully utilized. Thus, the lower the feed conversion value, the more efficiently the feed provided is used for growth and vice versa. The higher the feed conversion value, the more inefficient the feed provided is used for growth.

Water quality is an important factor in vaname shrimp culture, because it is needed as a living medium for shrimp and can affect shrimp body resistance. Measurement of water quality, salinity, temperature, $\mathrm{pH}$, and $\mathrm{DO}$, showed that all treatments were still in optimal conditions for vaname shrimp culture.

In this study, temperature measurements were carried out at 08.00-09.00 WITA, using a thermometer. Based on the results of temperature measurements during vaname shrimp rearing, the results obtained are temperatures of 26-30 $0 \mathrm{C}$. This temperature concentration is still within the normal limits of a good temperature for shrimp. According Arsad et al., (2017) , the optimum temperature for pertum harbor shrimp vaname range 28 $300 \mathrm{C}$. The results of observations show that the temperature is still in a good limit on the maintenance process. Temperature is very influential on photosynthetic activity and the solubility of the particles in it and physical, chemical and biological properties are also very influential on temperature which can affect the physiological life of cultivated organisms, if the temperature rise reaches certain limits it will increase the rate of shrimp growth (Iriani, 2004).

Salinity is one of the environmental parameters that affect the biological processes that directly will affect the life of the organism such as influence the growth rate, the amount of food consumed, food conversion value and power of survival. The osmotic pressure of water is also strongly influenced by salinity, so the higher the salinity, the greater the osmotic pressure. Salinity measured during the study ranged from 23-28 ppt. This 
Journal of Fish Health Vol. 1 (1) - Juni 2021

Akbar et al. (2021)

https://doi.org/10.29303/jfh.v1i1.162

salinity value is optimal for cultivation. According to Arsad et al. , (2017), the optimal salinity for the growth of white shrimp is $25-30$ ppt and has a wide salinity tolerance. Shrimp like salinity that is not too high, which is optimum at a salinity of 10-30 ppt, but shrimp can grow well at a salinity of 5-45 ppt.

The $\mathrm{pH}$ value in the waters describes the acid-base conditions of a waters. Table 1 shows that the $\mathrm{pH}$ values of all treatments were in the normal range, between 7-8. According Erland (2012), states that the ideal $\mathrm{pH}$ for growth vaname shrimp ranged from 7 , 5 -8.5. This $\mathrm{pH}$ range can be said to be supportive for the continuation of the shrimp farming business. He also stated (1992), the $\mathrm{pH}$ range good for shrimp farming that is 8 to 8,5 because that band shrimp can experience optimal growth. According to Effendi (2003) the value of the optimal $\mathrm{pH}$ range for shrimp growth ranged from $7,0-8.5$ and can tolerate a $\mathrm{pH}$ in the range 6.5 to 9.0. A pH that is below the tolerance range can cause disruption of the moulting process so that the skin becomes soft and viability is low.

At the optimum $\mathrm{pH}$ value the osmotic pressure between the rearing environment and the shrimp body is almost the same so that the shrimp does not require too much energy to carry out the osmoregulation process and more energy can be allocated for the growth process, in addition to the optimum $\mathrm{pH}$ value range the growth of pathogenic bacteria is inhibited. According to Boyd (1982) in Effendi (2003), the pH is below 6,5 or higher than 9.0 can reduce the ability of reproduction and growth. Thus the $\mathrm{pH}$ concentration in all treatments was still in normal conditions and was not harmful to shrimp.

Oxygen is one of the limiting factors for life in water, so if its availability in water is not sufficient for the needs of aquaculture biota, all activities of the biota will be hampered. According to Zhang et al. (2006) in Effendi (2003), oxygen demand in vaname shrimp is influenced by body weight, temperature, salinity, $\mathrm{pH}$, and feed because it has a significant effect on DO levels in white shrimp. According to Effendi (2003), temperature affects DO levels in water. At low temperatures DO levels increase, and at high temperatures DO levels decrease. DO measurement in this study was carried out every 7 days. Dissolved oxygen during the study ranged 5 , $22-6.19 \mathrm{mg} / \mathrm{L}$. This range is almost the same in all treatments, and is still in the safe limit. This refers to the statement of Ferreira et al. (2011) that DO levels required in shrimp growth in cultivation between the 4, 0 to $-6.0 \mathrm{mg} / \mathrm{L}$. If DO levels in low waters can result in growth and decreased appetite for biota.

\section{CONCLUSION}

Based on the results of the study showed that the administration of probiotics with different doses gave a significant effect on the survival rate of white shrimp (SR) and feed conversion ratio (FCR), but did not give a significant effect on absolute weight growth and daily weight growth. Administration of probiotics at a dose of $1 \mathrm{ml} / \mathrm{l} /$ week (P5) gave a better effect in increasing fish growth, SR, and FCR compared to other treatment doses.

\section{ACKNOWLEDGMENT}

In this opportunity, the researcher would like to thank the University of Mataram for facilitating and supporting during this research 
Journal of Fish Health Vol. 1 (1) - Juni 2021

Akbar et al. (2021)

https://doi.org/10.29303/jfh.v1i1.162

\section{REFERENCES}

Adiwidjaya, D., SP Raharjo, E. Sutikno and S. Subiyanto. 2003. Technical Instructions for Environmentally Friendly Closed System Vaname Cultivation. Ministry of Marine Affairs and Fisheries, Directorate General of Aquaculture, Center for the Development of Brackish Water Cultivation. $29 \mathrm{p}$.

Ahmadi, H., Iskandar., N. Kurniawati. 2012. Provision of Probiotics in Feed on the Growth of Sangkuriang Catfish ( Clarias graprienus ) in Nursery II. 3(4): 99-107.

Arsad, S., Ahmad, A., Atika, PP, Betrina, MV, Dhira, KS, Nanik, RB 2017. Study of Vaname Shrimp ( Litopenaeus vannamei) Enlargement Cultivation Activities with Application of Different Maintenance Systems. Scientific Journal of Fisheries and Marine Affairs 9 (1), 1-14.

Boyd, CE 1982. Water Quality Management for Pond Fish Culture. New York: Elsevier Science.

Cahyono, B. 2009. Cultivation of Freshwater Biota. Canisius. Yogyakarta.

Effendi, 1979. Location Determination Study for Marine Aquaculture Development Based on Physical, Chemical, and Biological Parameters in Kupang Bay, East Nusa Tenggara [Thesis, unpublished]. Diponegoro University. Semarang. Indonesia.

Effendi. 2003. Study of Water Quality for Water Resources and Environment Management. Kanisius : Yogyakarta.

Harefa, F., 1996. Cultivation of Artemia for Shrimp and Fish Feed. PT. Self-help spreader, Jakarta rta

Iriani, D. 2004. Evaluation of the Suitability of Coastal Land for the Development of Pond Cultivation in Purworejo Regency . Thesis. Diponegoro University, Semarang.

Khasani, I. 2011. Application of Probiotics Towards Sustainable Aquaculture Systems. Journal : Aquaculture Media 2 (2) : 86-149.

Kordi, MGH 2007. Management of Water Quality in Aquaculture. Rineka Cipta, Jakarta.

Lara-Flores, M., 2011. The use of probiotics in aquaculture: an overview. International Research Journal of Microbiology , 2 (12), pp.471-478.

Mayasari, E. 2013. The Effect of Lactic Acid Bacteria on the Survival of Tiger Grouper (Epinephelus fuscoguttatus). Thesis. Faculty of Fisheries and Marine Sciences, University of Riau.

Mudjiman, A. 2011. Fish Food. Self-help spreader, Jakarta.

Nasrul, 2019. The Effect of Probiotics with Different Doses on Maintenance Media on the Growth and Survival of Vannamei Shrimp ( Litopenaeus Vannamei ). Thesis. Faculty of Fisheries and Marine, University of Riau. Pekanbaru.

Poernomo, A. 2004. Teknologi Probiotik untuk Mengatasi Permasalahan Tambaj Udang dan Lingkungan Budidaya. Seminar Nasional Akuakultur 27-29 Januari 2004. Semarang. 20 hlm

Putra, AN 2010. Study of Probiotics, Prebiotics and Synbiotics to Improve Growth Performance of Tilapia (Oreochromis niloticus). Thesis. Graduate program. Bogor Agricultural Institute. Bogor. $91 \mathrm{p}$.

Ridlo, A. and Pramesti, R., 2009. Application of seaweed extract as an immunostimulant agent for non-specific defense systems in shrimp (Litopennaeus vannamei). MARINE SCIENCE : Indonesian Journal of Marine Sciences, 14 (3), pp.133-137.

Suryanto, $H$ and Mangampa, M,. 2010. Applications of Probiotics with Different Concentrations in Raising Vaname Shrimp ( Litopenaeus vannamei). Proceedings of the 
Journal of Fish Health Vol. 1 (1) - Juni 2021

Akbar et al. (2021)

https://doi.org/10.29303/jfh.v1i1.162

Aquaculture Technology Innovation Forum. Brackish Water Aquaculture Research Institute. Maros. South Sulawesi. 9 p.

Syaiful Anwar, 2015. The Effect of Commercial Probiotics in Feed on Growth Rate and Feed Efficiency of Vannamei Shrimp ( Litopenaeus vannamei). Journal of Aquaculture and Fish Health Vol 5 No.2. Airlangga University. Surabaya.

Wang, YB 2007. Effect of Probiotics on Growth Performance and Digestive Enzyme Activity of The Shrimp Penaeus vannamei. J. Aquaculture. 269(4): 254-264 .

Widanarni MA Lidaenni, and D. Wahjuningrum. 2010. The Effect of Giving Probiotic Bacteria Vibrio SKT-B With Different Doses on Survival And Growth Of Windu Shrimp Larvae ( Penaeus Monodon) Fab. Indonesian Journal of Aquaculture . 9. 29-29.

Zhang, PD, XM Zhang, and J. Li. 2006. The effect of body weight, temperature, salinity, $\mathrm{pH}$, light intensity and feeding condition on lethal DO levels of whiteleg shrimp, Litopenaeus vannamei (Boone, 1931 ). Aquaculture, 256:579-587 